\title{
Selection of common bean lines obtained by the genealogical and bulk methods for disease resistance and agronomic traits
}

\author{
Tamires Ribeiro ${ }^{1}$, Sara Regina Silvestrin Rovaris ${ }^{1 *}$, Jose Antonio de Fátima Esteves ${ }^{\mathbf{1}}$, \\ Sérgio Augusto Morais Carbonell ${ }^{1}$, and Alisson Fernando Chiorato ${ }^{1}$ \\ 'Instituto Agronômico (IAC), Caixa postal 28, 13001-970 Campinas, São Paulo, Brasil. \\ "Corresponding author(sara_rsr@yahoo.com.br).
}

Received: 15 January 2019; Accepted: 7 May 2019; doi:10.4067/S0718-58392019000300456

\begin{abstract}
A common bean (Phaseolus vulgaris L.) breeding program aims to obtain high yielding lines with quality bean seeds, disease resistance, and upright plant growth habit. The aims of this study were to evaluate the resistance of 527 common bean lines to the principal physiological races of Colletotrichum lindemuthianum and the Fusarium oxysporum f. phaseoli; to estimate genetic parameters and verify the efficiency of the genealogical and bulk methods in conducting these lines. Of these 527 lines, 279 were conducted by the genealogical method and 248 by the bulk method. For the field experiment, the Federer augmented block experimental design was used. Two commercial cultivars carioca seed coat were used as controls for the lines the same color, and more two commercial cultivars for the black seed coat lines. The traits evaluated in the field were plant height (PH), plant growth habit (P), bean seed yield (BY), sieve yield (SY), and lightness of the bean seed coat (L). Of the 527 lines evaluated for anthracnose, 207 were resistant, 57 moderately resistant, and 263 susceptible. For fusarium wilt, 58 were resistant, 53 moderately resistant, and 96 susceptible. For the carioca seed coat lines obtained by the genealogical method, the heritability $\left(\mathrm{h}^{2}\right)$ estimates stood out for P, BY, L at $40 \mathrm{~d}$, and gain from selection for BY. The $\mathrm{h}^{2}$ stood out for black seed coat lines in the PH and SY traits, it can be concluded that the lines obtained by the genealogical method had better performance for all the traits.
\end{abstract}

Key words: Anthracnose, autogamous plant breeding, fusarium wilt, gain from selection, heritability, Phaseolus vulgaris.

\section{INTRODUCTION}

Common bean (Phaseolus vulgaris L.) is a legume consumed by most Brazilians, including all social classes, especially the lower classes, for whom it is considered the main source of proteins, minerals, vitamins, and dietary fiber (Bassinello, 2009).

According to data of the Companhia Nacional de Abastecimento (CONAB, 2018), the estimate of Brazilian common bean crop for 2017-2018 is around 3.3 million tons. However, this production could be higher were it not for diseases such as fusarium wilt (Fusarium oxysporum f. sp. phaseoli) and anthracnose (Colletotrichum lindemuthianum), which may lead to reductions of $80 \%$ to $100 \%$ in bean seed yield in susceptible cultivars (Candida et al., 2009; Cruz et al., 2014). Management strategies, such as crop rotation, elimination of crop residues, and use of healthy seeds, have been used for control of these diseases. However, the use of resistant cultivars is the most efficient manner for maintaining the yield and seed quality of common bean (Candida et al., 2009).

Breeding programs do not aim to obtain only disease resistance and high yield in common bean, but also upright growth habit, a light colored seed coat, and sieve size greater than 12 for the carioca seed coat and above 11 for the black 
seed coat. These traits facilitate harvest and crop treatments, thus maintaining market value and consumer acceptance (Carbonell et al., 2010).

Given the wide range of traits to be incorporated in a single genotype by breeding programs, methods of conducting segregating populations assist in and optimize selection of populations with traits of interest. The bulk method and the genealogical method are those most used for breeding of autogamous plants. Jost et al. (2014) highlighted the genealogical method for obtaining common bean lines with high bean seed yield and an early cycle. Silva et al. (2013) found that the bulk method, within $\mathrm{F}_{2}$, had the highest indexes of generating common bean progenies with better performance for bean seed yield and crude fiber content.

The aims of this study were to evaluate 527 common bean lines conducted by the bulk and genealogical methods for resistance to physiological races 31,65, and 81 of Colletotrichum lindemuthianum and races 1 and 2 of Fusarium oxysporum f. sp. phaseoli; estimate the genetic parameters for growth habit and plant height, bean seed yield, sieve yield, and seed coat lightness; and verify the efficiency of the two methods used.

\section{MATERIALS AND METHODS}

We used 527 lines of common bean (Phaseolus vulgaris L.), consisting of 156 with carioca seed coat and 123 with black seed coat obtained by the genealogical method, and 92 lines of carioca seed coat and 156 of black seed coat by the bulk method. These lines were developed aiming to acquire the main traits required by the producer and consumer markets of the crop. These traits include resistance to the main races of the anthracnose and fusarium wilt pathogens since these are some of the main factors that reduce yield and lower the quality of bean seeds. The following traits were also in focus: plant growth habit and plant height to obtain more upright plants, bean seed yield, sieve yield, and seed coat lightness, to ensure bean seed quality for the consumer market.

\section{Field experiment}

A field experiment was conducted in 2013 in the winter crop season at the Central Experimental Center of the Santa Elisa Farm at Instituto Agronômico (IAC), Campinas ( $22^{\circ} 54$ S, $47^{\circ} 03$ W; $854 \mathrm{~m}$ a.s.1.), São Paulo, Brazil. The formulated fertilizer 04-14-08 was applied at sowing at the rate of $25 \mathrm{~g} \mathrm{~m}^{-1}$ in the planting furrow; this corresponds to $20 \mathrm{~kg} \mathrm{~N} \mathrm{ha}^{-1}$, $70 \mathrm{~kg} \mathrm{P}_{2} \mathrm{O}_{5} \mathrm{ha}^{-1}$, and $40 \mathrm{~kg} \mathrm{~K}_{2} \mathrm{O} \mathrm{ha}^{-1}$. Urea was topdressed $25 \mathrm{~d}$ after, applying $100 \mathrm{~kg} \mathrm{~N} \mathrm{ha}^{-1}$.

A Federer augmented block experimental design (Federer, 1955) was used, and the following commercial cultivars were used as controls: IAC Alvorada and IPR Tangará for the carioca seed coat lines, and IPR Tuiuiú and IAC Diplomata for the black seed coat lines. The plots were composed of $2.0 \mathrm{~m}$ length rows at a spacing of $0.5 \mathrm{~m}$ between rows and 24 plants per row.

The traits evaluated were plant growth habit (P, with 1 representing upright, 2 and 3 semi-upright, and 4 and 5 prostrate plants); plant height ( $\mathrm{PH}, \mathrm{cm}$ ); bean seed yield (BY, in $\mathrm{kg} \mathrm{ha}^{-1}$ ); sieve yield (SY, using $\mathrm{nr} 12$ sieve for the carioca bean and nr 11 for the black bean); lightness (L, in the unit of measurement, determined by a colorimeter device [CR-410 Chroma Meter; Konica Minolta, Tokyo, Japan], in the CIE 1976 scale system Lab*) or CIELab, in which the L* parameter represents the lightness scale from 0 to 100 .

The data obtained were analyzed with the assistance of the software Genes 2013 (Cruz, 2013) through ANOVA, and the following genetic parameters were determined: genetic coefficient of variation $(\mathrm{CVg})$; environmental coefficient of variation $(\mathrm{CVe})$, and the ratio between them $(\mathrm{CVg} / \mathrm{CVe})$; broad sense heritability:

$$
\hat{\mathrm{h}}_{\mathrm{a}}^{2}=\sigma_{\mathrm{g}}^{2} / \sigma_{\mathrm{f}}^{2}
$$

Where $\sigma_{g}^{2}$ is genotypic variance and $\sigma_{\mathrm{f}}^{2}$ is phenotypic variance; selection differential is sd $=\overline{\mathrm{X}}_{\mathrm{m}} \overline{\mathrm{X}}_{\mathrm{o}}$; gain from selection $(\mathrm{GS})=\mathrm{h}_{\mathrm{a}}^{2} \times$ sd broad sense heritability, $\overline{\mathrm{X}}_{\mathrm{m}}$ is mean of those selected and is $\overline{\mathrm{X}}_{\mathrm{o}}$ mean of the original population.

\section{Greenhouse experiments}

Greenhouse experiments were conducted in 2014 and 2015 in pots in a greenhouse at the Central Experimental Center of the Santa Elisa Farm, IAC. A randomized complete block experimental design was used, with four replicates, considering a pot with two plants as a replicate. 
For evaluation regarding anthracnose resistance, seeds from the 527 lines and from the susceptible control 'Pérola' were first disinfected with $70 \%$ ethyl alcohol and then with $1.25 \%$ sodium hypochlorite for $5 \mathrm{~min}$. After that, seeds were germinated in germination paper with neutral $\mathrm{pH}$ and placed in biochemical oxygen demand (BOD) for $3 \mathrm{~d}$ at $28^{\circ} \mathrm{C}$. After this period, the seedlings were transplanted in pots containing $500 \mathrm{~g}$ substrate (organic compost:soil 1:1). The isolates 13.373-1 (race 31), 14786 (race 81), and 14670 (race 65) of Colletotrichum lindemuthianum (Sacc. \& Magnus) Briosi \& Cavara, coming from the Plant Health Center of the IAC were multiplied in oat medium (oat and agar). The inoculum was standardized to $1 \times 10^{6}$ conidia $\mathrm{mL}^{-1}$ in a Neubauer chamber. Inoculation was performed spraying at the $\mathrm{V} 2$ stage of seedling development according to the scale proposed by Gepts and Fernández (1982). The seedlings were kept in a moist chamber at $20^{\circ} \mathrm{C}$ for $48 \mathrm{~h}$ with a $12: 12 \mathrm{~h}$ photoperiod. After that, moisture control was turned off, and plants remained for $10 \mathrm{~d}$ at $20^{\circ} \mathrm{C}$. Evaluation was made using the scale described by Balardin et al. (1990), with scores from 1 to 9, with 1 representing a plant completely free of symptoms and 9 representing necrosis, leaf dropping, and plant death.

The lines that showed resistance to anthracnose were tested for resistance to races 1 and 2 of Fusarium oxysporum $\mathrm{f}$. phaseoli J.B. Kendr. \& W.C. Snyder. The seeds of the lines and of 'IAC Alvorada' and 'Rosinha $\mathrm{G}_{2}$ ' (controls susceptible to the pathogen) were pre-germinated under laboratory conditions and transplanted to trays containing sterilized vermiculite. For inoculation, isolates 14428 (race 1) and FOP 46 (race 2) from the Plant Health Center of IAC were multiplied in PDA

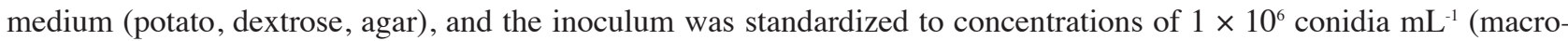
and microconidia) in a Neubauer chamber. Seedlings were inoculated in the V2 stage of seedling development according to the scale proposed by Gepts and Fernández (1982) by the dipping method, in accordance with Costa et al. (1989). After inoculation, plants were transplanted in pots containing $500 \mathrm{~g}$ substrate (organic compost:soil 1:1) and placed in a greenhouse for $30 \mathrm{~d}$. Symptoms were evaluated using a scoring scale developed by Nascimento et al. (1995), where 0 is absence of symptoms and 4 is plants that are completely wilted or dead.

\section{RESULTS AND DISCUSSION}

\section{Diseases}

The 527 lines developed by the genealogical and bulk methods were evaluated for resistance to races 31,65 , and 81 of $C$. lindemuthianum - 207 lines (39\%) were found to be resistant, 57 (11\%) moderately resistant, and 263 (50\%) susceptible. Considering only the resistant lines, 126 were conducted by the genealogical method, consisting of 53 with a carioca seed coat and 73 with a black seed coat, and 81 were conducted by the bulk method, consisting of 33 with a carioca seed coat and 48 with a black seed coat. The black seed coat lines of the genealogical and bulk methods stood out compared to the carioca seed coat lines.

The 207 lines resistant to the anthracnose pathogen were evaluated in regard to race 1 (American) and race 2 (Brazilian) of $F$. oxysporum f. phaseoli: 58 lines (28\%) were resistant, 53 (26\%) moderately resistant, and $96(46 \%)$ susceptible. Considering only the resistant lines, 32 were conducted by the genealogical method, consisting of 15 carioca seed coat lines and 17 black seed coat lines, and 26 by the bulk method, consisting of 13 carioca seed coat lines and 13 black seed coat lines.

The black seed coat lines, regardless of the experimental method, stood out for resistance to races 31,65 , and 81 of the anthracnose pathogen. These results were expected because these lines originated from crosses made with 'IAC Una' and 'IAC Diplomata', resistant to the main physiological races already identified in Brazil (Chiorato et al., 2015). It should be noted that anthracnose is one of the main diseases that affect common bean and, according to Ribeiro et al. (2016), 10 races of the pathogen have been identified in the state of São Paulo, with races 65 and 81 occurring most frequently. Furthermore, the authors emphasized the high physiological variability among the isolates of race 65 of the pathogen, which shows the importance of using resistant cultivars to maintain the yield and seed quality of common bean.

Silva et al. (2009) evaluated 143 common bean lines and obtained $87 \%$ resistance to race 65 of the anthracnose pathogen. Zuiderveen et al. (2016) evaluated 230 common bean lines for eight races of the pathogen $(7,39,55,65,73,109,2047$, and 3481 ) and indicated $12 \%$ resistance to six races and only one cultivar resistant to all the races evaluated. In the present study, $39 \%$ resistance to races 31,65 , and 81 of the pathogen was observed; however, the wide variability and the different levels of aggressiveness of the races found in the main common bean production regions in Brazil require a constant search for resistant cultivars in breeding programs (Ribeiro et al., 2016), reinforcing the importance of the present study. 
Only $28 \%$ resistance to races 1 and 2 of fusarium wilt pathogen was observed in the lines evaluated. Chiorato et al. (2015) evaluated 25 common bean cultivars and indicated 32\% resistance to races 1 and 2 of the fusarium wilt pathogen. According to Xue et al. (2015), the low percentage of resistance of common bean to this pathogen is related to the response of plant defense to $F$. oxysporum $\mathrm{f}$. phaseoli, which involves expression of a large number of gene fragments in different regions of the genome, complicating and intensifying the work of selecting resistant cultivars.

Garcés-Fiallos et al. (2017) emphasized that the pathogen colonizes the shoot tissues of susceptible cultivars, resulting in earlier and more evident symptoms, reducing the number of seeds per pod and seed weight, directly affecting bean seed yield. Moreover, the authors reported that even in resistant cultivars, the pathogen reduces yield, affecting the number of pods per plant and seed weight. However, it is not as drastic as in susceptible cultivars, and this makes the crop yield levels viable even though the pathogen is widespread in common bean production regions.

The fact of obtaining sources of resistance to these pathogens does not imply that the lines will exhibit suitable commercial traits, such as plant height, upright growth habit, bean seed yield, sieve yield, and seed coat lightness. For that reason, many lines were used in this study so as to obtain reliable sources of resistance that also have the traits desired by producers and consumers of common bean, thus ensuring acceptance of the genotypes selected.

\section{Estimates of genetic parameters}

The use of different methods of conducting the experiment is important for evaluating which are more advantageous for the traits of interest, speeding the breeding process and making it more practical for obtaining new common bean cultivars.

The estimates of genetic parameters obtained for plant growth habit (P), plant height (PH), bean seed yield (BY), sieve yield (SY), and seed coat lightness (L) of the lines conducted by the genealogical and bulk methods exhibited different values. These results allowed selection of lines with better performance for these traits as well as analysis of the efficiency of the methods of conducting the segregating populations (Tables 1 and 2).

Broad sense heritability of the lines obtained by the genealogical method regarding the traits evaluated ranged from $19.12 \%$ to $99.83 \%$, and for the bulk method, from $5.87 \%$ to $99.84 \%$. In relation to the carioca seed coat lines conducted by the genealogical method, estimates of $\mathrm{h}^{2}$ stood out for P (79.24\%), BY (58.62\%), SY (68.40\%), and L of $40 \mathrm{~d}(99.48 \%)$ and $120 \mathrm{~d}(99.83 \%)$, whereas in the black seed coat lines, estimates stood out for PH (68.40\%), SY (98.91\%), and L of $40 \mathrm{~d}(99.45 \%)$. In relation to the carioca seed coat lines obtained by the bulk method, estimates of $\mathrm{h}^{2}$ stood out for $\mathrm{P}$ (87.60\%), PH (83.50\%), and L of $40 \mathrm{~d}(99,00 \%)$ and $120 \mathrm{~d}(99.59 \%)$, and for the black seed coat lines, estimates of $\mathrm{h}^{2}$ stood out for BY (77.11\%), SY (95.25\%), and L of $40 \mathrm{~d}$ (99.84\%). Rocha et al. (2015) evaluated the yield of 48 carioca and black seed coat common bean progenies and reported broad sense heritability estimates ranging from $6.80 \%$ to $70.31 \%$, results that are similar to those presented in this study. Silva et al. (2013) compared lines obtained by the bulk and single seed descent (SSD) methods and found maximum values of broad sense heritability for BY of $49.8 \%$. From the estimates of broad sense heritability presented in this study for the black seed coat lines in the bulk method and carioca

Table 1. Estimates of genetic parameters for plant growth habit, plant height, bean seed yield, sieve yield, and seed coat lightness in 156 lines of carioca seed coat lines and 123 black seed coat lines obtained by the genealogical method. Campinas, São Paulo, Brazil, 2013.

\begin{tabular}{|c|c|c|c|c|c|c|c|c|c|c|c|}
\hline \multirow[b]{2}{*}{ Parameter } & \multicolumn{2}{|c|}{ Plant growth habit } & \multicolumn{2}{|c|}{ Plant height } & \multicolumn{2}{|c|}{ Bean seed yield } & \multicolumn{2}{|c|}{ Sieve yield } & \multicolumn{3}{|c|}{ Seed coat lightness } \\
\hline & Carioca & Black & Carioca & Black & Carioca & Black & Carioca & Black & $\mathrm{C} 40 \mathrm{~d}$ & $\mathrm{C} 120 \mathrm{~d}$ & $\mathrm{P} 40$ \\
\hline$\hat{\mathrm{h}}_{\mathrm{a}}^{2}$ & 79.24 & 29.15 & 25.99 & 68.40 & 58.62 & 19.12 & 68.40 & 98.91 & 99.48 & 99.83 & 99.45 \\
\hline$\hat{\sigma}_{f}^{2}$ & 0.64 & 1.30 & 39.22 & 2927.50 & 3126.33 & 2300.58 & 2927.50 & 1567.93 & 329.90 & 279.32 & 64.75 \\
\hline$\hat{\sigma}_{\mathrm{g}}^{2}$ & 0.51 & 0.38 & 10.19 & 2002.50 & 1832.58 & 439.90 & 2002.50 & 1550.08 & 328.21 & 278.91 & 64.40 \\
\hline$\overline{\mathrm{X}}$ & 2.89 & 2.56 & 44.03 & 49.50 & 1495.00 & 1368.00 & 63.92 & 26.82 & 53.45 & 53.17 & 23.21 \\
\hline$\overline{\mathrm{X}}_{\mathrm{s}}$ & 1.75 & 2.00 & 45.90 & 51.55 & 1680.00 & 1390.00 & 85.84 & 55.00 & 52.51 & 51.83 & 23.01 \\
\hline GS & -0.90 & -0.16 & 0.49 & 1.40 & 108.45 & 4.21 & 14.99 & 27.87 & -0.94 & 1.32 & -0.20 \\
\hline $\mathrm{CVe}$ & 12.65 & 12.68 & 12.23 & 45.68 & 25.79 & 34.03 & 47.58 & 15.41 & 2.42 & 1.34 & 2.56 \\
\hline $\mathrm{CVg}$ & 24.73 & 24.32 & 7.25 & 67.20 & 29.93 & 16.32 & 67.21 & 143.01 & 33.85 & 33.36 & 34.63 \\
\hline $\mathrm{CVg} / \mathrm{CVe}$ & 1.95 & 0.64 & 0.59 & 1.47 & 1.19 & 0.49 & 1.47 & 9.53 & 13.96 & 24.76 & 13.49 \\
\hline
\end{tabular}

$\hat{\mathrm{h}}_{\mathrm{a}}^{2}$ : Broad sense heritability; $\hat{\sigma}_{\mathrm{f}}^{2}$ : phenotypic variance; $\hat{\sigma}_{\mathrm{g}}^{2}$ : genotypic variance; $\overline{\mathrm{X}}$ : overall means; $\overline{\mathrm{X}}_{\mathrm{s}}$ : means of selected individual plant; GS: gains from selection; CVe: environmental coefficient of variation; CVg: genetic coefficient of variation. 
Table 2. Estimates of genetic parameters for plant growth habit, plant height, bean seed yield, sieve yield, and seed coat lightness in 92 carioca seed coat lines and 156 black seed coat lines obtained by the bulk method. Campinas, São Paulo, Brazil, 2013.

\begin{tabular}{|c|c|c|c|c|c|c|c|c|c|c|c|}
\hline \multirow[b]{2}{*}{ Parameter } & \multicolumn{2}{|c|}{ Plant growth habit } & \multicolumn{2}{|c|}{ Plant height } & \multicolumn{2}{|c|}{ Bean seed yield } & \multicolumn{2}{|c|}{ Sieve yield } & \multicolumn{3}{|c|}{ Seed coat lightness } \\
\hline & Carioca & Black & Carioca & Black & Carioca & Black & Carioca & Black & $\mathrm{C} 40 \mathrm{~d}$ & $\mathrm{C} 120 \mathrm{~d}$ & $\mathrm{P} 40$ \\
\hline$\hat{\mathrm{h}}_{\mathrm{a}}^{2}$ & 87.60 & 24.95 & 83.50 & 48.62 & 5.87 & 77.11 & 45.73 & 95.25 & 99.00 & 99.59 & 99.84 \\
\hline$\hat{\sigma}_{f}^{2}$ & 1.07 & 1.22 & 57.91 & 56.47 & 1374.41 & 8127.04 & 1247.55 & 359.77 & 274.96 & 248.22 & 68.33 \\
\hline$\hat{\sigma}_{g}^{2}$ & 0.94 & 0.30 & 48.35 & 27.45 & 80.66 & 6266.34 & 570.46 & 342.69 & 277.71 & 247.23 & 68.22 \\
\hline$\overline{\mathrm{X}}$ & 3.07 & 2.27 & 46.32 & 47.72 & 1277.00 & 1101.00 & 35.61 & 10.59 & 58.97 & 53.81 & 23.27 \\
\hline$\overline{\mathrm{X}}_{\mathrm{s}}$ & 2.25 & 2.57 & 53.12 & 48.35 & 1346.00 & 1125.00 & 42.00 & 35.00 & 57.91 & 53.67 & 23.36 \\
\hline GS & -0.72 & 0.07 & 5.68 & 0.31 & 4.05 & 18.51 & 2.92 & 23.25 & -1.04 & -0.14 & 0.09 \\
\hline $\mathrm{CVe}$ & 11.81 & 42.17 & 6.62 & 11.60 & 30.58 & 43.51 & 73.08 & 39.02 & 3.08 & 1.98 & 1.39 \\
\hline $\mathrm{CVg}$ & 31.31 & 24.04 & 14.84 & 11.26 & 7.44 & 80.48 & 65.76 & 187.80 & 30.84 & 31.17 & 35.54 \\
\hline $\mathrm{CVg} / \mathrm{CVe}$ & 2.65 & 0.57 & 2.24 & 0.97 & 0.25 & 1.84 & 0.92 & 4.48 & 9.99 & 15.74 & 25.49 \\
\hline
\end{tabular}

$\hat{\mathrm{h}}_{\mathrm{a}}^{2}$ : Broad sense heritability; $\hat{\sigma}_{\mathrm{f}}^{2}$ : phenotypic variance; $\hat{\sigma}_{\mathrm{g}}^{2}$ : genotypic variance; $\overline{\mathrm{X}}$ : overall means; $\overline{\mathrm{X}}_{\mathrm{s}}$ : means of selected individual plant; GS: gains from selection; CVe: environmental coefficient of variation; CVg: genetic coefficient of variation.

seed coat lines in the genealogical method, it can be inferred that a favorable gain from selection is expected for BY. This result is possible since broad sense heritability values of $50 \%$ or more can be manipulated and determine its influence for repeatability of the trait in the next generations, indicating the predominance of genetic effects over environmental ones and lending greater progress to the traits of interest (Chagas et al., 2016). The higher estimate of broad sense heritability for BY was indicated by the black seed coat lines conducted by the bulk method (77.11\%), a result similar to that reported by Jost et al. (2014), indicating low environmental influence for BY. In relation to genetic variances, Silva et al. (2013) evaluated common bean progenies obtained by the bulk method and found estimates of 29769.6 and $11591.5 \mathrm{~kg} \mathrm{ha}^{-1}$ for BY, values superior to those found in this study, which ranged from 80.66 to $6266.34 \mathrm{~kg} \mathrm{ha}^{-1}$. According to Ramalho et al. (2012), among the methods of conducting segregating populations, the bulk method stands out through maintaining variability among the lines selected, regardless of the generation in which sampling was carried out; the variability of the $\mathrm{F}_{2}$ generation populations was similar. Nevertheless, various factors can affect the efficiency of the bulk method, such as the action of natural selection, losses resulting from the sampling process, and the effects of the Genotype $\times$ Environment interaction, exerting a considerable influence on expression of quantitative traits like bean seed yield (Silva et al., 2013).

The values of phenotypic variances for P, PH, BY, SY, and L were superior to the genotypic variances for the two experimental methods used, indicating environmental influence on expression of these traits. The genotypic variances shown by the genealogical method were superior to those of the bulk method for the traits of BY, SY, L40, and L120 d for the carioca seed coat lines and for P, PH, and SY for the black seed coat lines. In the present study, the greatest genetic variances were observed in the genealogical method for all the traits evaluated, except for $\mathrm{P}$ and $\mathrm{PH}$ in the carioca seed coat lines and for BY and L (40 d) in the black seed coat lines. According to Borém and Vieira (2009), the advantages of this method occur through control of kinship between generations, elimination of inferior plants in earlier generations, and the use of data obtained for genetic studies. However, disadvantages are higher costs for development, as in larger experimental fields and increased demand for qualified labor to select desirable plant types.

Gains from selection (GS) for P were of low magnitude and exhibited negative values for the lines obtained by the two experimental methods, except for the black seed coat lines of the bulk method, which exhibited positive GS, though of low magnitude. Considering that plant growth habit is evaluated by a scoring scale in which lower scores represent upright plants, these negative gains, even though of low magnitude, are promising for breeding programs because more upright plants facilitate crop treatments. The GS for PH were of low magnitude and positive for the two experimental methods. For BY, superior GS were observed for the genealogical method, mainly for the carioca seed coat lines, which exhibited the best estimate, resulting in a gain of $108 \mathrm{~kg} \mathrm{ha}^{-1}$. For SY, GS were also superior in the genealogical method, and the carioca seed coat lines stood out, with an estimate of 14.90, and those of black seed coat, with 27.61. For bulk, the carioca seed coat lines exhibited an estimate of GS for SY of 2.87, and those of black seed coat, of 23.18. For L, gains from selection for both methods were negative and of low magnitude, except for the black seed coat lines conducted by the genealogical method. Based on these results, the selected carioca seed coat lines that exhibited a lower degree of seed coat 
darkening stand out. This trait is extremely relevant for breeding programs, allowing better acceptance of the beans by the consumer market. Pontes Júnior et al. (2016) evaluated fiber content in common bean progenies and indicated gain from selection of $4.45 \%$ for the bulk method, $2.97 \%$ for SSD, and $1.86 \%$ for the bulk method within $\mathrm{F}_{2}$ families. Silva et al. (2013) obtained greater genetic gain compared to the study of Pontes Júnior et al. (2016), but with the same ratio between the methods, with the bulk method standing out. These authors worked with the same population, using $\mathrm{F}_{7}$ progenies that were tested in two locations. For plant architecture, the values presented by these authors were superior to those obtained in the present study for the two experimental methods, making it difficult to obtain more upright plants. In the present study, the highest GS were observed in the bulk method in the carioca seed coat lines for P, PH, and L, and in the black seed coat lines for BY and SY. The P and PH traits are relevant when we consider mechanized harvest conditions because more upright plants facilitate this type of harvest (Silva et al., 2009). The ideal plant for mechanized harvest should be taller than $50 \mathrm{~cm}$, with resistance to lodging, such as the cultivars selected in the present study, emphasizing that this is a trait to be considered in releasing a new cultivar, ensuring its acceptance by producers. BY and SY are fundamental for selection of new cultivars since yield and bean seed size are the main objectives of breeding programs. Another relevant factor is a lower degree of seed coat darkening, ensuring acceptance by the consumer market. In the genealogical method, the highest estimates were for P, BY, SY, and L for the carioca seed coat lines and PH and SY for the black seed coat lines.

The coefficients of environmental variation (25.79\%) and genetic variation (29.93\%) exhibited similar values in regard to BY in the carioca seed coat lines obtained by the genealogical method. The same situation was observed for the SY trait in the carioca seed coat lines conducted by the bulk method, indicating a situation favorable to selection because the $\mathrm{CVg} / \mathrm{CV}$ ratio indicates a value near 1 . The values of the genotypic coefficient of variation $(\mathrm{CVg})$ of the lines obtained by the genealogical method ranged from $7.25 \%$ to $143.01 \%$, and by the bulk method, from $7.44 \%$ to $187.80 \%$. Estimates of the $\mathrm{CVg}$, with high magnitude values $(66 \%$ and $98 \%$ ) indicate the reliability of the mean phenotypic value as a predictor of the genotypic value, characterizing a favorable situation for the selection process (Moura et al., 2013). Thus, the CVg estimates stand out for BY (black seed coat) and SY (black and carioca seed coat) by the bulk method and for PH (black seed coat) and SY (black and carioca seed coat) by the genealogical method, favoring the selection process. Regis et al. (2014) found a CVg of $28.44 \%$ for BY, which was similar to that observed in the present study for the carioca seed coat lines conducted by the genealogical method (29.93\%) and lower than that for the black seed coat lines conducted by the bulk method (80.48\%). The information generated by the genetic parameters is of fundamental importance in the selection processes since it provides data on heritability, prediction of genetic gains, evaluation of the potentialities of a determined population, and the relative efficiency of the selection methods, allowing identification of the most efficient selection methods (Hallauer and Miranda Filho, 1981).

Based on the results of the evaluations performed, 29 lines with better performance were able to be selected, 14 (5\%) conducted by the genealogical method and 15 (6\%) by the bulk method. The lines C10-2-6/1, C10-2-17/2, C10-6-2/5, P10-1-9/38, C10-2-4/41, Pr10-4-3/12, Pr10-3-3/15-1, Pr10-3-3/15-2, Pr10-4-1/1, Pr10-3-6/2, Pr10-3-3/4, Pr10-3-3/1, $\operatorname{Pr} 10-3-3 / 3$, and Pr10-3-2/7 coming from the genealogical method, showed resistance to the two pathogens evaluated, semi-upright or upright growth habit, and, for lines $\operatorname{Pr} 10-3-6 / 2$ and Pr10-3-2/7, high yield and bean seed quality. Lines C10-2-4/35, C10-2-4/41, C10-2-16/5, P10-1-9/38, C10-2-4/35, P10-1-3/1, P10-1-4/2, Pr10-4-2/10, Pr10-4-3/12, C10-21/2, Pr10-4-4/38, Pr10-5-2/1, Pr10-4-4/8-1, Pr10-4-4/8-2, and Pr10-3-5/35, coming from the bulk method, also exhibited resistance to the two pathogens evaluated. However, plant growth habit was semi-upright, upright, or prostrate, which was expected through the use of selection by sampling. The lines C10-2-16/5, C10-2-4/35, Pr10-4-2/10, Pr10-4-4/8-1, and Pr10-4-4/8-2 exhibited high yield and bean seed quality. From the promising values of the estimates shown by the lines, the genealogical method stands out, especially considering the traits of P, BY, SY, and L, important for the release of new cultivars. The 14 lines obtained by the genealogical method, namely, C10-2-6/1, C10-2-17/2, C10-6-2/5, P10-1-9/38, C10-2-4/41, Pr10-4-3/12, Pr10-3-3/15-1, Pr10-3-3/15-2, Pr10-4-1/1, Pr10-3-6/2, Pr10-3-3/4, Pr10-3-3/1, Pr10-3-3/3, and Pr10-3-2/7, exhibited resistance to the two pathogens evaluated, semi-upright or upright growth habit, higher yield than the lines obtained by the bulk method, higher percentage of sieve yield, and bean seeds that were lighter colored and with a lower degree of seed coat darkening. These lines can be placed in the next value of cultivation and use of beans (VCU) tests, allowing new cultivars to be extracted with traits of interest for producers and consumers of bean seeds. 


\section{CONCLUSION}

Of the 527 common bean lines obtained by the genealogical and bulk method, 207 exhibited resistance to races 31,65 , and 81 of anthracnose pathogen, and 58 to races 1 and 2 of fusarium wilt pathogen.

By the genetic parameters shown for the traits of plant growth habit, bean seed yield, sieve yield, and seed coat lightness, the genealogical method stands out for conducting segregating populations.

We were able to select 14 lines obtained by the genealogical method with resistance to the anthracnose and fusarium wilt pathogens, semi-upright or upright growth habit, high bean seed yield and sieve yield, and seed coats that had lighter color and a lower degree of darkening. These are the traits required by the common bean producer and consumer markets.

\section{REFERENCES}

Balardin, R.S., Pastor-Corrales, M.A., e Otoya, M.M. 1990. Variabilidade patogênica de Colletotrichum lindemuthianum no Estado de Santa Catarina. Fitopatologia Brasileira 15:243-245.

Bassinello, P.Z. 2009. Qualidade nutricional, funcional e tecnológica do feijão. p. 385-424. In Kluthcouski, J., Stone, L.F., e Aidar, H. (eds.) Fundamentos para uma agricultura sustentável, com ênfase na cultura do feijoeiro. Embrapa Arroz e Feijão, Santo Antônio de Goiás, Goiás, Brasil.

Borém, A., e Vieira, G. 2009. Melhoramento de plantas. 5ª ed. 529 p. Universidade Federal de Viçosa (UFV), Viçosa, Minas Gerais, Brasil.

Candida, D.V., Costa, J.G.C., Rava, C.A., e Monalisa, S.C. 2009. Controle genético da murcha do fusário (Fusarium oxysporum) em feijoeiro comum. Tropical Plant Pathology 34(6):379-384.

Carbonell, S.A.M., Chiorato, A.F., Gonçalves, J.G.R., Perina, E.F., e Carvalho, C.R.L. 2010. Tamanho de grão comercial em cultivares de feijoeiro. Ciência Rural 40:2067-2073.

Chagas, K., Alexandre, R.S., Schmildt, E.R., Bruckner, e C.H., Faleiro, F.G. 2016. Divergência genética em genótipos de maracujazeiro azedo, com base em características físicas e químicas dos frutos. Revista Ciência Agronômica 47:524-531.

Chiorato, A.F., Carbonell, S.A.M., Bosetti, F., Sasseron, G.R., Lopes, R.L.T., and Azevedo, C.V.G. 2015. Common bean genotypes for agronomic and market-related traits in VCU trials. Scientia Agricola 72(1):34-40.

CONAB. 2018. Levantamento de safra. Companhia Nacional de Abastecimento. Available at http://www.conab.gov.br/ OlalaCMS/uploads/arquivos/17_08_10_11_27_12_boletim_graos_agosto_2017.pdf (accessed 15 July 2018).

Costa, A.F., Coelho Netto, R.A., e Miranda, P. 1989. Métodos de inoculação de Fusarium oxysporum F. sp. phaseoli em feijão visando seleção de linhagens resistentes. In Congresso Brasileiro de Fitopatologia, Brasília. Sociedade Brasileira de Fitopatologia. Fitopatologia Brasileira 14:135.

Cruz, C.D. 2013. Genes - a software package for analysis in experimental statistics and quantitative genetics. Acta Scientiarum. Agronomy 35:271-276.

Cruz, M.F.A., Araujo, L., Polanco, L.R., e Rodrigues, F.A. 2014. Aspectos microscópicos da interação feijoeiro Colletotrichum lindemuthianum mediados pelo silício. Bragantia 73(3):284-291.

Federer, W.T. 1955. Experimental design: Theory and application. 544 p. Oxford \& IBH Publishing Company, Delhi, India.

Garcés-Fiallos, F.R., Borba, M.C., Schmidt, E.C., Bouzon, Z.L., and Stadnik, M.J. 2017. Delayed upward colonization of xylem vessels is associated with resistance of common bean to Fusarium oxysporum f. sp. phaseoli. European Journal of Plant Pathology 147:1-18.

Gepts, P., y Fernández, F. 1982. Etapas de desarrollo de la planta de frijol común (Phaseolus vulgaris L.) 10 p. Centro Internacional de Agricultura Tropical (CIAT), Cali, Colombia.

Hallauer, A.R., and Miranda Filho, J.B. 1981. Quantitative genetics in maize breeding. 468 p. Iowa State University Press, Ames, Iowa, USA.

Jost, E., Ribeiro, N.D., Rosa, D.P., Possobom, M.T.D.F., and Maziero, S.M. 2014. Methods of selecting common bean lines having high yield, early cycle and erect growth. Revista Ciência Agronômica 45(1):101-110.

Moura, M.M., Carneiro, P.C.S., Carneiro, J.E.S., e Cruz, C.D. 2013. Potencial de caracteres na avaliação da arquitetura de plantas de feijão. Pesquisa Agropecuária Brasileira 48(4):417-425.

Nascimento, S.R.C., Kurozawa, C., e Maringoni, A.C. 1995. Avaliação de raças fisiológicas de Fusarium oxysporum f. sp. phaseoli. Fitopatologia Brasileira 20(2):214-217.

Pontes Júnior, V.A., Melo, P.G.S., Pereira, H.S., and Melo, L.C. 2016. Genetic potential of common bean progenies obtained by different breeding methods evaluated in various environments. Genetic Molecular Research 15(3):gmr.15038622.

Ramalho, M.A.P., Abreu, A.F.B., Santos, J.B., e Nunes, J.A.R. 2012. Aplicações da genética quantitativa no melhoramento de plantas autógamas. 522 p. Editora UFLA, Lavras, Minas Gerais, Brasil.

Regis, J.A.V.B., Molinas, V.S., Santos, A., Correa, A.M., e Ceccon, G. 2014. Estimativas de parâmetros genéticos em Genótipos de feijão-caupi de porte ereto e semiereto. Revista Agrarian 7(23):11-19. 
Ribeiro, T., Esteves, J.A.F., Silva, D.A., Gonçalves, J.G.R., Carbonell, S.A.M., and Chiorato, A.F. 2016. Classification of Colletotrichum lindemuthianum races in differential cultivars of common bean. Acta Scientiarum. Agronomy 38(2):179-184.

Rocha, G.S., Carneiro, J.E.S., Carneiro, P.C.S., Poersch, N.L., Lima, M.S., e Silva, L.C. 2015. Estratégias de predição e efeitos de ambientes na avaliação de populações segregantes de feijão. Revista Ceres 62(5):438-445.

Silva, C.A., Abreu, A.F.B., e Ramalho, M.A.P. 2009. Associação entre arquitetura de planta e produtividade de grãos em progênies de feijoeiro de porte ereto e prostrado. Pesquisa Agropecuária Brasileira 44:1647-1652.

Silva, A.C.F., Melo, P.G.S., Melo, L.C., Bassinello, P.Z., e Pereira, H.S. 2013. Eficiência de métodos de melhoramento para teor de fibra e produtividade de grãos em progênies de feijoeiro comum. Bragantia 72(4):326-331.

Xue, R., Wu, J., Zhu, Z., Wang, L., Wang, X., Wang, S., et al. 2015. Differentially expressed genes in resistant and susceptible common bean (Phaseolus vulgaris L.) genotypes in response to Fusarium oxysporum f. sp. phaseoli. PLOS ONE 10(6): 0127698.

Zuiderveen, G.H., Padder, B.A., Kamfwa, K., Song, Q., and Kelly, J.D. 2016. Genome-wide association study of anthracnose resistance in Andean beans (Phaseolus vulgaris). PLOS ONE 11(6):e0156391. 